\title{
R
}

\section{Om frizoner i dansk byplanlægning}

af Martin Søberg og Djawed Kimouche 


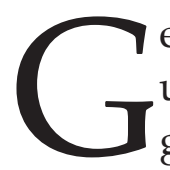

ennem de senere år er snakken i kredse med interesse for byer og byudvikling gået om, hvordan midlertidige aktiviteter og områder kan gøres til en institutionaliseret del af fremtidens byplanlægning (Hausenberg 2008:6). Fremhævelsen af de midlertidige aktiviteter dækker over et bredt spektrum af urbane hændelser fra begivenheder af kort varighed som festivaler, loppemarkeder, kunstudstillinger og piratfester i byens rum til aktiviteter af længere varighed som strandbarer, haver, egentlige byrumsomdannelser og etableringen af nye kulturhuse. De midlertidige aktiviteter finder ofte sted i områder, der er under udvikling, enten som resultat af fysiske ændringer i og med etableringen af den postindustrielle by, hvor fabrikker og værksteder ofte står tomme efter en outsourcing og deraf følgende funktionstømning, eller som led i brandingen af nye, ofte monotone kvarterer, der savner identitet, variation og spontanitet og derfor må tilføres et skud gøgl for at opnå det højt besungne byliv. Brugen af midlertidighed anbefales og siges ligefrem at kunne "få en vigtig strategisk funktion for byerne" (Pløger 2008:53) $\mathrm{i}$ forhold til at styrke den interurbane konkurrence. Især under den seneste lavkonjunktur er midlertidighed blevet et mantra og et løfte om, at denne type aktiviteter i disse rum kan slå et slag for kulturen og samtidig gøde jorden, indtil investorerne igen er risikovillige og investeringslystne. Hele byer arbejder nu med midlertidigheden som del af en samlet city-branding og kulturstrategi i målet om at øge andelen af livsstilsturister såvel som kreative videnarbejdere, hvis kompetencer direkte lader sig omsætte til økonomiske parametre i den stadig hårdere konkurrence mellem vestlige storbyer.

En del opmærksomhed er især blevet de ombejlede rum til del, hvilket igen har produceret en del navne med hver deres teoretiske ophav eller metaforiske begribelsesforsøg. Her er blot nogle af de mange begreber, som det urbane kollektiv Supertanker har fundet frem til:

... wastelands, derelict areas, No man's land, Dead Zones, urban "voids", Terrain vague, Vacuums, indeterminate spaces, weak places, spaces without function, empty spaces, niches, cracks, gaps, interstices, unused spaces, non-places, junkspaces, temporary autonomous zones, spaces left over from planning, intermediate time-spaces, liminal spaces, transition spaces, fallow land, waiting land, residual spaces, obsolete land, fringes, brownfields ... (Supertanker 2008:9).

Men hvor de fysiske rum i høj grad er blevet betegnet, synes selve driften, aktørerne og deres motivationer for at tage rummene i brug at være stærkt underbelyst (Groth \& Corijn 2004:13). Denne mangel på viden viser sig også at være ret så symptomatisk for de forskellige kommunale og kommercielle forsøg på at omfavne de såkaldte midlertidige aktiviteter. 


\section{Kulturelle frizoner}

Seneste har vi i postkasser og e-mail-indbakker modtaget Københavns Kommunes folder "CO:OPENHAGEN", hvori man støder på begrebet "midlertidige kulturelle frizoner" (Københavns Kommune 2010:2). Disse zoner skal være medvirkende til at give unge mulighed for at sætte præg på byen. Ikke overraskende er det steder som Nordhavnen og Ørestad, der er sat i spil. Hvor Nordhavnen er planlagt som ny bydel på tidligere havnearealer, er Ørestad en bydel, der er hastet igennem på bar mark og først nu skriger på det byliv, der skal bidrage til at give København "en central og naturlig rolle som ledende international storbyregion i Østersøområdet" (Københavns Kommune 2001:39). Kommunens valg af frizone er dog foreløbig faldet på Carlsberg Byen af alle steder (FriZonen, http://frizone.dk). Med basis i egne erfaringer som "urbane pionerer" undrer vi os imidlertid over, hvordan kommunale instanser og private virksomheder er kommet frem til, at de aktivt kan planlægge og skabe frizoner, og ikke mindst hvordan urbane aktører som led heri tilsyneladende sådan uden videre tænkes at ville lade sig spænde for en vogn, der omhandler kommunale udviklingsperspektiver og kommerciel spekulation?

Vi finder det derfor oplagt at se på noget af den litteratur, som informerer kommuner og virksomheder. Det etnografisk/antropologiske og samfundsvidenskabelige analysefirma Hausenberg har med rapporten "Midlertidige aktiviteter som værktøj i byudviklingen" (Hausenberg 2008), bestilt af Århus Kommune, søgt at give et svar på spørgsmålet. Men allerede i indledningen står det os klart, at en fundamental viden om frizoner er gået tabt:

Fremkomsten af midlertidige aktiviteter som et særligt fænomen i byudviklingen er i høj grad knyttet til overgangen fra industri- til videnssamfund (Hausenberg 2008:4).

Og forfatterne fortsætter:

De midlertidige aktiviteter opstod som krøllede ideer hos folk, som forstod at udnytte muligheden for at gøre noget anderledes på steder, som ingen andre fandt attraktive (Hausenberg 2008:5).

Her vil vi ikke desto mindre påpege, at benyttelsen af "no man's land" er en drift, der har eksisteret igennem hele menneskets historie, ikke kun i en partikulær overgang fra industri- til videnssamfund. Der er talrige eksempler på, at folk er flygtet og har taget ophold i midlertidige heller eller "safe havens"(Groth \& Corijn 2004:12). At danne frizoner er således ikke kun motiveret af "krøllede ideer", men af en reel erfaring med mangel på anerkendelse og mulighed for overlevelse. Som sådan har dannelsen af frizoner en lang historie, eller man kunne sige, at midlertidige aktiviteter og dannelsen 
af frizoner i det mindste er en permanent, urban betingelse. Tænk blot på katakomberne, der eksempelvis har fungeret som bastioner for kristendommen og i Paris den dag i dag bruges af ildestedte undergrundsmiljøer.

Ikke alle midlertidige frizoner har fungeret som flugtzoner. Socialteoretikeren Kevin Hetherington har blandt andet fremhævet, hvorledes PalaisRoyal i Paris under den franske revolution blev omdannet til kommercielt brug og var samlingspunkt for et bredt udsnit af befolkningen fra lav til høj. Palæet dannede ramme om en kreativ og kritisk masse, der bidrog aktivt til revolutionen. Altså ser vi en form for frizone, hvor fælles modstand mod hegemoniet blev mobiliseret under en vis festivitas (Hetherington 1997). Urbanisterne Jacqueline Groth og Eric Corijn kan tilsvarende nævne eksempler som karthanere, assasinere og sågar byen Hong Kong som en art frizone. De konkluderer, at:

... historic freezones turn out to have been of particular importance for the origins of urban culture, the expansion of states, the protection of minorities and the renewal of the city. In short, they have been essential during all phases in the development of urban society (Groth \& Corijn 2004:12).

Hakim Bey er nok den teoretiker, der har fremlagt flest eksempler på midlertidige og heterogene fællesskaber og beskrevet dem som "temporary autonomous zones", altså zoner, hvori sædvaner for en periode tilsidesættes (Bey 1991). Blandt hans mere underholdende og "Richard Floridaske" eksempler er hændelserne i Fiume. Efter første verdenskrig holdt kommandøren Gabrielle D’Annunzio mod Italiens ønske byen Fiume i det nuværende Kroatien besat i 18 måneder og erklærede musikken som det centrale styringsprincip, hvilket betød, at han spillede trompet fra balkonen hver morgen. Kunstnere, bohemer, eventyrer, anarkister, flygtninge, statsløse, homoseksuelle, militære dandyer, teosofister, buddhister, vedantister og mange andre valfartede til byen (Bey 1991:124). Igen er det under stor festivitas, at disse marginale identiteters flugt fra hegemoniet udtrykker sig. Ønsket om politiske, kulturelle, sociale og økonomiske forandringer går således hånd i hånd med en æstetisk nyorientering i muligheden for at etablere et kritisk korrektionsrum.

Denne forbindelse mellem en politisk og socioøkonomisk og en æstetisk villighed til forandring er ikke mindst effektiv, fordi den æstetiske oplevelse i sig selv er en temporær autonom zone. Den tyske filosof Hans-Georg Gadamer har peget på kunstværkets autonome temporalitet som en fundamental æstetisk betingelse for oplevelsen af værket, svarende til det, man oplever under en festival. Kunstværket modsætter sig således i bedste fald indskrivningen i eksisterende dagsordener i og med sin formålsløshed og gennem aktiveringen af mennesket i den æstetiske oplevelses rytmiske spil (Gadamer 1986:42-43). Den æstetiske oplevelse perspektiverer eller fremsætter nye bud 
på virkeligheden og kan dermed facilitere kulturelle såvel som politiske og socioøkonomiske forandringer.

Af nyere eksempler på, hvorledes frizoner kan påvirke bykulturen, vil vi nævne rydningen af Ungdomshuset i København. Stik imod hensigten blev rydningen startskuddet til en omfattende og spektakulær kritisk praksis. Ud over ugentlige demonstrationer i myldretiden var byen fyldt med events, happenings, gadekunst, besættelser af bygninger og tilegnelser af upåagtede rum, der blev dannet om til haver og opholdsrum, ligesom det kom til en syv uger lang besættelse af Refshalevej på Christianshavn (Wikstrøm \& Hallgrimsdottir (eds.) 2010:97-102). Med krav fra borgere og heftig kritik af ungdomspolitikken blandt andet fra Politigården kunne kommunen ikke længere sidde kritikken overhørig. Et banner til en af de sidste "Torsdagsdemoer" lød: "Før var vi 500, nu er vi 5000". Kommunen kvitterede med et nyt ungdomshus og reagerede yderligere proaktivt ved at finde bygninger, der kunne rumme et Københavns Projekthus "for og af unge".

\section{Men for hvem?}

Som eksemplerne belyser, har frizoner en vis historisk permanens og i det mindste altid været en del af byens liv. De har fungeret som politiske mobiliseringszoner, ligesom de har rummet flygtninge af enhver art. Men den dynamik, som frizonerne er eksponenter for, bliver notorisk ignoreret, når der i dag begejstret tales om "midlertidige kulturelle frizoner" som middel til bymæssig revitalisering. Det lyder ellers meget godt, som en win-win situation, indtil man får kigget nærmere på hvilke aktører, der skal skabe frizonen - og på hvilke betingelser. Senest har begivenhederne i Brorsons Kirke vist, at det tydeligvis ikke er flygtninge, illegale indvandrere og psykisk syges behov for et helle, der skal tilgodeses i skabelsen af byer af internationalt format. Men hvem så? I Københavns Kommunes Kulturstrategi 2009-2011 fremgår det blot, at "unge" er målgruppen (Københavns Kommune 2009:9). Det er et vidt begreb! Tilsvarende i Indenrigs- og Socialministeriets publikation "Mental byomdannelse", der på baggrund af blandt andet erfaringer fra Tyskland, Norge og Holland skal hjælpe de danske kommuner med at tænke midlertidig brug af byrum og bygninger ind i byernes fysiske transformation. Her hedder det, at:

Uanset om motivet er kommercielt eller ej, er byrumspionererne en enorm ressource, som kan bruges i en dynamisk byudvikling (Boye et al. 2009:14).

Stadig med uklarhed om, hvem disse pionerer er. Hausenberg kommer igen til hjælp med en mulig definition. Under overskriften "De urbane pionerer" (Hausenberg 2008:10) opdeles disse i fire typologier: "Opdyrkerne", "migranterne", "ideologerne" og "deltidsaktivister". På bedste instrumentaliserende vis får vi fortalt, at: 
"Opdyrkerne" og "migranterne" er de typer, som har lettest ved at finde overlappende interesser med andre aktører, så længe de blot har mulighed for at realisere deres personlige drøm. De evner i vidt omfang at indordne sig under gældende lovgivning og kan i mange tilfælde også acceptere, at deres aktiviteter indgår i markedsføringen af en bydel eller et produkt. De er ofte bevidste om deres placering i en oplevelsesøkonomisk logik (Hausenberg 2008:11).

Ideologer og deltidsaktivister er derimod ikke interesserede i at indgå i denne logik. De offentlige strategiers ensidige fokus på kultur, i smalleste forstand, og særligt udvalgte typer er således udtryk for en ekstrem redigering og kastrering af det historiske frizonebegreb og af den politiske, æstetiske og sociale dynamik, der ellers kendetegner den heterogene frizone. Med det institutionaliserede frizone-koncept søges der ikke at etablere et fællesskab, der rækker ud over den kulturinteresserede gruppe. Ej heller handler det om at skabe en form for (ny) offentlighed, der ellers siden Richard Sennetts bog The Fall of Public Man (Sennett 1977) er blevet enten begrædt tabt eller pragmatisk accepteret af postmodernister som Jean-Francois Lyotard, der mente, at muligheden for at undslippe kapitalismens omsiggribende kolonisering ikke længere var til stede. Noget kunne tyde på, at Lyotard havde ret. De politiske, sociale eller kulturelle initiativer er ikke frie i zonen, men søges indskrevet i en økonomisk logik, hvor mennesker i tråd med tidens managementkultur anses som ressourcer i mere end fysisk forstand.

\section{Zonens død}

Mens behovet for at etablere frizoner er relativt permanent, er eksistensen af den enkelte frizone ofte midlertidig. Dette kan skyldes flere faktorer: Enten har de opløst sig selv, de har formået at skabe sig plads i kulturen og derved gjort zonen unødvendig, eller de er blevet skubbet ud eller udraderet. Som Groth og Corijn skriver:

... it has to be stated that the main actors determining the "legal" status of these types of actions are both the local authorities and the proprietors. They determine whether the temporary activities are repressed or not (Groth \& Corijn 2005:521).

I byplanssammenhænge er begrebet midlertidighed altså en omskrivning af planlagt død. Det ligger fra begyndelsen fast, at kommunen eller den private virksomhed som hovedregel kommer til at agere bøddel.

En klassisk dødsårsag er, at "pionererne bliver ofre for deres egen succes" (Hausenberg 2008:6). Senest er det set i Carlsberg Byen i det tidligere Carlsberg-bryggeri i Valby, hvor man blandt andet har etableret det kommunale samarbejdsprojekt "FriZonen" og inviteret kunstnere til at benytte byen for en lav husleje. Lejen stiger dog med den øgede efterspørgsel, og de første 
kunstnere er allerede flyttet igen, skubbet ud af andre kunstnere med et bedre økonomisk fundament. En anden strategi er den kontraktbaserede tilgang, som Roskilde Kommune benytter i det tidligere industriområde Unicon, nu kaldet Musicon, for at skabe en kreativ bydel. "I byomdannelsesprojektet $\mathrm{Mu}$ sicon i Roskilde tillader kommunen en lang række midlertidige aktiviteter i Frizonen" (Hausenberg 2008:9). Et centralt element er "en bevidst og aktiv brug af midlertidige funktioner til at fremme endemålet" (Roskilde Kommune 2005:3). Her får hver udvalgt aktør en kontrakt, som "skal sikre konkrete nu og her-resultater" (Roskilde Kommune 2005:18). På sigt bliver resultaterne evalueret af bestyrelsen og kommunen, så de "bedste" kan få lov til at fortsætte og blive "permanente" (Hausenberg 2008:19). Den kreativitet, der altså skal udfolde sig i "Frizonen", er ikke åben, men skal bevæge sig hen imod, at stedet bliver attraktivt, hvorved:

de traditionelle virkemidler som bindende fysisk planlægning, arkitekt- eller projektkonkurrence osv. tages i anvendelse i takt med, at de rette samarbejdspartnere og købere viser sig. Indtil da arbejdes der i åben dialog (Roskilde Kommune 2005:18).

Aktørerne er altså bundet op på at levere produktive ideer, på evaluering og på intern konkurrence med øvrige kontraktholdere. Endvidere er kreativiteten i "Frizonen", hvis den skal have en mulighed for at overleve, forpligtet til at understøtte "endemålet". "Frizonens" potentiale for at blive et arnested for kritik eller det radikalt åbne er dermed effektivt sat ud af spil! I stedet må man leve med frygten for en vurdering som uværdig og inkompetent.

En tredje model er den uformelle/kontraktløse. Denne tilgang spekulerer i ikke at etablere et lejeforhold med tilhørende rettigheder; aktørerne er så at sige uden vished for, hvornår man kan blive sagt op. Denne tilgang har flere eksempler både i Århus og Københavns Kommuner og i privat ejendom. Freie Internationale Tankstelle (FIT) er et internationalt kunstkoncept, hvor tomme tankstationer bliver omdannet til kunsttanke. En sådan blev etableret på Nørrebro i København i efteråret 2009. Kunstnerne tog kontakt til tankstationens ejer, der syntes om ideen, blandt andet fordi den befriede ham for vedligeholdelse af stedet (Kjær 2010). Tanken blev istandsat, og der summede af aktivitet. Flere kunstnere deltog, og flere aktivister fulgte med i processen. Et netværk var etableret (Interview m. "Christian" 2010). Dog havde projektet problemer med en lokal caféejer, der fra start mente, at stedet udgjorde et konkurrenceproblem. Én af aktivisterne, "Christian", fortæller, at de havde regnet med at beholde stedet, til det en dag blev solgt. Men en dag ringede ejeren af tanken. Han var træt af at blive ringet op af caféejeren og meddelte FIT, at det var deres sidste chance:

Det var meget mærkeligt, og vi vidste ikke, hvad det var, vi gjorde forkert, naboerne var jo glade for os. Og ejeren af caféen ville slet ikke i dialog med os. 
Han uddyber usikkerheden:

Det var meget diffuse rammer, ejeren havde givet os, sidste chance for hvad? Hvad er det, vi ikke gjorde rigtigt? Vi var helt handlingslammede.

Da caféejeren blev ved med at sende klager, trak ejeren af tankstationen til sidst stikket ud.

Det var ret nedslående, vi havde jo brugt en del tid på at opbygge stedet og var først lige begyndt at fungere. Det er sgu' spild af ressourcer og erfaring. Netværket er jeg heller ikke sikker på kan holde, når der ikke er et sted, vi kan mødes, derfor er vi også begyndt at lede efter nyt.

"Christian" fortæller, at de til det sidste håbede på at kunne få lov til at blive, og at de i stedet for at gå i stå accelererede mængden af kunst og begivenheder, "for at vise vores værd". FIT eller det såkaldte "voksnes ungdomshus" (Kjær 2010) lukkede i slutningen af maj 2010.

Som eksemplerne viser, er muligheden for at skabe reelle frizoner meget begrænsede. Enten er de offentlige intentioner mere eller mindre hule, og de midlertidige rum tilbudt med henblik på gentrificering, hvor succes er lig med pionerernes visse død. Eller de er cooptations-strategier, hvor zonerne får afmonteret deres demokratiske og kritiske potentiale, og aktørerne sættes i en usikker og stressende tilstand, der tvinger dem til at fokusere på sikring af gruppens egen enhed og værdi. Mulighederne for at tænke frizonen som radikalt åben, som et heterogent, inddragende og inkluderende fællesskab, der kan bidrage med udfordringer til samfundet, synes altså stærkt begrænsede. I stedet for at tage udfordringen og viljen til at forandre samfundet alvorligt ved brug af frizonen som inspiration, bliver den skamredet. På institutionelt niveau bliver de midlertidige aktiviteter gjort til strategiske planmæssige indslag, der skal fornøje, æstetisere og slippe små lunser af hedonisme, blot aktiviteterne ikke sætter sig permanente spor eller bryder med endemålet. De får ingen indeksikale virkninger, men eksisterer blot som symbolske gestus, en kalkuleret tolerance. Som små fordrejninger af rummet med kortsigtet inddragelse af den enkelte borger. Midlertidige aktiviteter bliver led i byplanlægning som mental manøvre eller mental udrensning. Udøverne er midlertidigt frie og symboler på en tolerance, der i sidste ende ikke vil vide af dem som reelle medspillere i byen. Ad forskellige manøvrer har man, som eksemplerne illustrerer, sikret en øjeblikkelig undertrykkelse, hvis de "frit" handlende pionerer udfordrer samfundets institutioner for meget. At komme uden om den “kognitive kapitalisme" (Nepper Larsen 2008), hvor menneskers frihedstrang og mulighedsudfoldelse bliver gjort til cool cash, synes dermed at være noget af en udfordring. 


\section{Bolsjefabrikken - Københavns største skulptur}

Er alt håb da ude? Selvfølgelig ikke - det er netop vores pointe! For at drage et aktuelt eksempel ud af mange, kan vi som aktivister i foreningen Bolsjefabrikken, der aktuelt har base i to lokaliteter i henholdsvis Københavns Nordvestkvarter og i grænselandet mellem Østerbro og Nørrebro, samt en tvillingesøster på Teglholmen i Sydhavnen, fortælle, at det styrende og motiverende for engagementet i steder som disse netop er undsigelsen af nogle af de logikker, der gør sig gældende i resten af samfundet. Alternativer kan finde sted. Aktiviteterne bliver ikke betragtet som podninger af nedslidte områder, men som reelle bud på andre, mere autonome og tolerante kultur-, organiserings- og samværsformer. For hvor det kommunale ønske om kortvarige, festlige indslag kan synes motiveret af netop disses midlertidige karakter, er dette ikke altid tilfældet for frizonens aktører. Det tidsmæssige og rumlige perspektiv forskydes, skønt man naturligvis er klar over midlertidigheden som betingelse for at kunne indtage lokaler til lav eller ingen leje.

Bolsjefabrikken kan, i lighed med andre frizoner, med den franske sociolog Pascal Nicholas-Le Strats ord beskrives som et "mikroeksperiment", hvori indgår forstyrrelser af den tidslige og rumlige forståelse (Nicholas-Le Strats 2007). Mikroeksperimentets potentiale består i at kunne udfordre makroplanets eksisterende ordener:

The micro represents a glimpse, a flash - a snapshot, as it were, of society. It is able to crystallize a number of social issues precisely because it doesn't allow itself to be slowed down by the most weighty and obvious institutional limits. In this sense, the micro is also a form of withdrawal from power, as Deleuze understands it, while keeping in mind that a return to power can happen just as quickly. Nevertheless, in the space-time that takes shape between withdrawals from and returns to power, the micro plane will have allowed a gap to open up, will have made a breach or a hole, something that is of the order of desire. An intensity (Nicholas-Le Strat 2007:4).

Bolsjefabrikken adskiller sig da også netop fra klubben eller den traditionelle forening gennem ønsket om at pege ud over sig selv og egne interesser, mod byen, i taktiske manøvrer mod den stadige strømligning af hverdagslivets normalisering og i brud med den generiske bys kommercielle neoliberalistiske logikker, som følge af hvilke alt er ens, uanset hvor vi befinder os. Ved at fordre deltagelse, eksperiment, hvile og engagement, fungerer stederne på rent frivillig basis, der skabes et tilhørsforhold og en identitet, der hverken kan købes/sælges eller er indskrevet i en kommunal eller statslig udviklingsstrategi. Snarere end bruger er man aktiv skaber og genskaber af en voksende og levende skulptur. Klog af skade (vi har allerede mistet ét sted) anvender vi endvidere taktiske og strategiske manøvrer; via vores rumlige spredning, 
med hver sin ejer og brugsaftale, forsøger vi at sikre os mod at stå uden et sted at få varme, anerkendelse og at kunne mobilisere fra i den nærliggende fremtid. Endvidere arbejder vi ihærdigt med at etablere og har etableret netværker og samarbejder med forskellige aktører både "nedadtil" med andre frizoner og græsrødder, "udadtil" med lokalområdets foreninger, en plads i lokaludvalget på Bispebjerg og eksponering via pressen, og "opad" via uformelle kontakter til det kommunalpolitiske system. Netop gennem bevægelsen i mange retninger påvirker vi byen.

Er Bolsjefabrikken så et succesfuldt foretagende? Det kan vi næppe selv vurdere, men vi stoler på kaos. Det forekommer at være særdeles vanskeligt at etablere en kritisk position i dag, hvor kritikken muligvis blot kan beskrives som en implicit korrektion af kapitalismen. Vi kan vel næppe planlægge heterotopien? Erfaringen viser, at forsøg med åben planlægning og indskrivning af det "Christiania-agtige", med "porøse" tilstande eller sprækker i kontrollen, vanskeligt lader sig forene med ejendomsspekulation, planlovgivning og den kommunale forestillingsevne. Og netop derfor er vi interesserede i midlertidige aktiviteter, i frizonen, der ikke handler om det midlertidige per se, men som opstår med forhåbning om det, der kunne være anderledes.

P.S.: Bolsjefabrikken holder fællesmøder 1. og 2. søndag i måneden. Måske.

Martin Søberg

E-mail: martinsoeberg@gmail.com

Djawed Kimouche

E-mail: djawedkimouche@gmail.com

\section{Litteratur}

Bey, Hakim 1991: The Temporary Autonomous Zone. New York: Autonomedia.

Boye, Anne Mette et al. 2009 : Mental byomdannelse. Midlertidig anvendelse som kick starter for en omdannelsesproces. København: Indenrigs- og Socialministeriet.

Gadamer, Hans-Georg 1986: The relevance of the beautiful and other essays. Cambridge: Cambridge University Press.

Groth, Jacqueline \& Eric Corijn 2004: "The Shadow City". Urban Unlimited, Maj, 2004:763.

Groth, Jacqueline \& Eric Corijn 2005: "Reclaiming urbanity". Urban Studies, Nr. 42, 2005: 503-26.

Hausenberg 2008: Midlertidige aktiviteter som værktøj i byudviklingen. Århus: Århus Kommune, Tænketanken for infrastruktur og byudvikling 2037.

Hetherington, Kevin 1997: The Badlands of Modernity: Heterotopia and Social Ordering. London: Routledge. 
Kjær, Birgitte 2010: “Naboklager lukker de voksnes ungdomshus”, Politiken/ibyen, d. 28. maj 2010.

Københavns Kommune 2001: Københavns Kommuneplan. Københavns Kommune.

Københavns Kommune 2009: Københavns Kommunes Kulturstrategi 2009-2011, Københavns Kommune - Kultur- og Fritidsforvaltningen.

Københavns Kommune 2010: CO:OPENHAGEN, sammen åbner vi byen, Københavns Kommune.

Nepper Larsen, Steen 2008: "Kritik af den kognitive kapitalisme". Dansk Sociologi, Nr. 4, 2008:87-92.

Nicolas-Le Strat, Pascal 2007: Micrology/Micrologies. Paris (hentet 1. juni 2010 på www.iscra.eu/fichier.php?id=149)

Pløger, John 2008: "Midlertidige byrum", i Juul, Helle et al. (red.): Byens rum 1. Det fremmede $i$ det kendte. København: Arkitekturforlaget B.

Roskilde Kommune 2005: Plan for en bydel. Roskilde Kommune.

Sennett, Richard 1977: The Fall of Public Man. Cambridge: Cambridge University Press.

Supertanker 2008: “Vague spaces between lived experiences and the floating and empty signifiers of "creativity"".

Wikstrøm, Kjersti \& Hulda Hallgrimsdottir (eds.) 2010: Get Lost - Et atlas over det (u) mulige København. København: Dansk Arkitektur Center.

\section{$\varnothing$ vrige kilder}

Interview med aktivisten “Christian", d. 11. juni 2010, København.

FriZonen, http://frizone.dk 